\title{
Penerapan Model Teams Games Tournament Berbantuan Media Pemprof untuk Meningkatkan Hasil Belajar Siswa Kelas IV Sekolah Dasar
}

\author{
Prisma Adi Putra ${ }^{1}$, Erik Aditia Ismaya ${ }^{2}$, Muhammad Noor Ahsin ${ }^{3}$ \\ Universitas Muria Kudus \\ Email: erik.aditia@umk.ac.id
}

\begin{tabular}{|c|c|}
\hline Info Artikel & Abstract \\
\hline $\begin{array}{l}\text { Keywords: } \\
\text { learning outcome, } \\
\text { team game tournament, } \\
\text { various occupations, } \\
\text { game media. }\end{array}$ & $\begin{array}{l}\text { The purpose of this study is to analyze the improvement of teacher skills and } \\
\text { increase learning outcomes of students in class IV SD } 5 \text { Lau in learning Theme } 4 \text { by } \\
\text { applying the learning model Team Games Tournament assisted by the Pemprof } \\
\text { media. The research method used is classroom action research (CAR) carried out in } \\
\text { two cycles, each cycle consisting of four stages namely planning, implementation, } \\
\text { observation and reflection. The research location is SD } 5 \text { Lau which is located at } \\
\text { Lau Village RT } 05 \text { / RW } 05 \text { Dawe District, Kudus Regency. The subjects of the study } \\
\text { were the fourth grade students of SD } 5 \text { Lau in the first semester of the } 2019 / 2020 \\
\text { school year, totaling } 16 \text { students, consisting of eight male students and eight female } \\
\text { students. Research data sources are teachers and students. Data collection } \\
\text { techniques include interview, observation, test and documentation techniques. The } \\
\text { validity of the data used is Expert Judgment using qualitative and quantitative data } \\
\text { analysis techniques. The results showed an increase in teacher teaching skills as } \\
\text { well as student learning outcomes in the realm of knowledge and the realm of skills. } \\
\text { The teaching skills of teachers in the first cycle obtained a percentage of } 76 \% \text { and } \\
\text { in the second cycle increased to 85.50\% Student learning outcomes in the realm of } \\
\text { social science content in the first cycle obtained an average of } 76.25 \text { with } 75 \% \\
\text { classical completeness and Indonesian content with an average } 73.12 \text { with classical } \\
\text { completeness } 56.25 \% \text {. In the second cycle the IPS load increased for an average of } \\
77.5 \text { with a classical completeness of } 81.25 \% \text { and an Indonesian content with an } \\
\text { average of } 84.06 \text { with a classical completeness of } 81.25 \% \text {. Student learning } \\
\text { outcomes in the realm of cycle I gained a percentage of 70.57\%, increasing in cycle } \\
\text { II to } 80.08 \% \text {. }\end{array}$ \\
\hline
\end{tabular}

\begin{abstract}
Abstrak
Tujuan penelitian ini yaitu menganalisis peningkatan keterampilan guru dan peningkatan hasil belajar siswa kelas IV SD 5 Lau pada pembelajaran Tema 4 dengan menerapkan model pembelajaran Team Games Tournament berbantuan media Pemprof. Metode penelitian yang digunakan yakni penelitian tindakan kelas (PTK) yang dilaksanakan dalam dua siklus, setiap siklus terdiri dari empat tahap yakni perencanaan, pelaksanaan, observasi dan refleksi. Lokasi penelitian di SD 5 Lau yang beralamat di Desa Lau RT 05/RW 05 Kecamatan Dawe Kabupaten Kudus. Subjek penelitian yaitu siswa kelas IV SD 5 Lau semester I tahun ajaran 2019/2020 yang berjumlah 16 siswa, terdiri dari delapan orang siswa laki laki dan delapan orang siswa perempuan. Sumber data penelitian yaitu guru dan siswa. Teknik pengumpulan data meliputi teknik wawancara, observasi, tes, dan dokumentasi. Validitas data yang digunakan yaitu Expert Judgement dengan menggunakan teknik analisis data kualitatif dan kuantitatif. Hasil penelitian menunjukkan adanya peningkatan pada keterampilan mengajar guru serta hasil belajar siswa ranah pengetahuan dan ranah keterampilan. Keterampilan mengajar guru pada siklus I memperoleh persentase $76 \%$ dan pada siklus II meningkat menjadi $85,50 \%$ Hasil belajar siswa ranah pengetahuan muatan IPS pada siklus I memperoleh rata-rata 76,25 dengan ketuntasan klasikal 75\% dan muatan Bahasa Indonesia dengan rata-rata 73,12 dengan ketuntasan klasikal 56,25\%. Pada siklus II meningkat untuk muatan IPS memperoleh rata-rata 77,5 dengan ketuntasan klasikal $81,25 \%$ dan muatan Bahasa Indonesia dengan rata-rata 84,06 dengan ketuntasan klasikal $81,25 \%$. Hasil belajar siswa ranah keterampilan siklus I memperoleh persentase $70,57 \%$ meningkat pada siklus II menjadi $80,08 \%$.
\end{abstract}

@ 2021 Universitas Muria Kudus 


\section{PENERAPAN MODEL TEAM GAMES TOURNAMENT BERBANTUAN MEDIA PEMPROF UNTUK MENINGKATKAN HASIL BELAJAR SISWA KELAS IV SEKOLAH DASAR}

JURNAL PRASASTI ILMU Volume 1 Nomor 1 hlm. 1 - 12

\section{PENDAHULUAN}

Pada tahun pelajaran 2013/2014 Pemerintah Indonesia menetapkan kurikulum baru dalam sistem pendidikannya yaitu Kurikulum 2013 yang merupakan penyempurnaan Kurikulum Tingkat Satuan Pendidikan 2006 (KTSP 2006). Pembaruan kurikulum ini dimaksudkan agar kualitas pendidikan di Indonesia menjadi lebih baik dan berkualitas. Ibrahim (2014) menyatakan "sejauh ini, Kurikulum 2013 merupakan kurikulum terbaik yang pernah dimiliki sekolah di Indonesia".

Salah satu penekanan dalam Kurikulum 2013 yaitu pembelajaran yang berpusat pada siswa (student center learning) sehingga siswa dapat membangun pengetahuan, sikap, dan keterampilan secara mandiri dan bermakna bagi dirinya. Adapun implementasi pembelajaran pada Kurikulum 2013 dilaksanakan secara tematik terpadu. Ekowati (2014) menyebut bahwa pembelajaan tematik adalah pembelajaran terpadu yang menggunakan tema untuk mengaitkan beberapa mata pelajaran sehingga dapat memberikan pengalaman bermakna kepada siswa. Model pembelajaran tematik menekankan pada pola pengorganisasian materi yang terintegrasi dipadukan oleh berbagai tema.

Kurikulum yang baik dan berkualitas tidak mempunyai arti jika tidak dilaksanakan secara benar oleh guru dalam pembelajaran di kelas. Dalam melaksanakan kurikulum 2013, guru harus melakukan inovasi dengan penggunaan model dan media pembelajaran yang tepat sehingga meningkatkan kualitas pembelajaran. Semakin baik kualitas pembelajaran maka semakin baik pula hasil belajar peserta didik. Namun yang menjadi masalah yaitu sering kali seorang guru dalam pembelajaran belum menggunakan model maupun media pembelajaran yang tepat sebagaimana yang terjadi pada pembelajaran di kelas IV SD 5 Lau Kecamatan Dawe Kabupaten Kudus.

Berdasarkan wawancara dengan guru kelas IV pada Kamis 27 Juli 2019 diketahui bahwa pembelajaran yang dilakukan masih berpusat pada guru (teacher center learning), guru belum menggunakan media pembelajaran yang inovatif dalam menyampaikan materi, dan sumber belajar siswa hanya sebatas buku paket. Sementara itu berdasarkan keterangan guru serta observasi terhadap buku nilai siswa diketahui bahwa hasil belajar siswa pada ulangan harian mata pelajaran Ilmu Pengetahuan Sosial (IPS) dan Bahasa Indonesia masih banyak yang berada di bawah KKM.
Untuk ulangan harian IPS diketahui jumlah siswa yang tuntas sebanyak lima orang dengan persentase $31,25 \%$, sedangkan yang tidak tuntas sebanyak 11 orang dengan persentase $68,75 \%$. Adapun untuk ulangan harian Bahasa Indonesia jumlah siswa yang tuntas sebanyak enam orang dengan persentase $37,5 \%$ dan yang tidak tuntas sebanyak sepuluh orang dengan persentase $62,5 \%$.

Berdasarkan permasalahan tersebut diatas maka guru perlu meningkatkan kualitas pembelajarannya. Salah satu caranya yaitu menggunakan model pembelajaran yang tepat. Ardianti, dkk (2018: 36) menyebutkan model pembelajaran adalah bentuk pembelajaran yang tergambar dari awal sampai akhir yang disajikan secara khas oleh guru di kelas. Model pembelajaran perlu digunakan guru agar materi pelajaran dapat tersampaikan kepada siswa dengan maksimal. Salah satu model pembelajaran yang dapat digunakan yaitu model pembelajaran Team Games Tournament. Model pembelajaran Team Games Tournament (TGT) merupakan teknik pembelajaran dengan menggabungkan kelompok belajar dengan kompetisi tim, dan bisa digunakan untuk meningkatkan pembelajaran beragam fakta konsep dan keterampilan (Silberman, 2006).

Model pembelajaran TGT dipilih karena peneliti melihat pembelajaran di kelas IV SD 5 Lau terlihat kaku dan kurang menarik minat siswa sehingga diperlukan unsur permainan (game) agar pembelajaran lebih menyenangkan dan dapat menarik minat siswa. Alasan berikutnya yaitu bahwa dalam pembelajaran belum terlihat rasa bersaing pada diri siswa untuk mencapai hasil belajar terbaik sehingga perlu diciptakan kompetisi antar siswa dengan menghadirkan unsur turnamen (tournament) dalam pembelajaran. Adapun langkah dalam pembelajaran model Team Games Tournament sebagai berikut 1) penyajian kelas, yaitu guru menyampaikan materi pembelajaran kepada siswa, 2) team (kelompok) yaitu pembentukan kelompok yang terdiri 4 sampai 5 siswa yang anggotanya heterogen dilihat dari prestasi akademik, 3) game yaitu terdiri dari pertanyaan-pertanyaan yang dirancang untuk menguji pengetahuan siswa, 4) tournament yaitu sebuah struktur yang berisi kompetesi dalam game yang sedang berlangsung, 5) rekognisi tim yaitu pemberian penghargaan kepada tim sesuai skor yang diperoleh.

Pemilihan model pembelajaran Team Games Tournament (TGT) sebagai upaya perbaikan serta peningkatan kualitas 


\section{PENERAPAN MODEL TEAM GAMES TOURNAMENT BERBANTUAN MEDIA PEMPROF UNTUK MENINGKATKAN HASIL BELAJAR SISWA KELAS IV SEKOLAH DASAR}

JURNAL PRASASTI ILMU Volume 1 Nomor 1 hlm. 1 - 12

pembelajaran pada siswa kelas IV SD 5 Lau Kecamatan Dawe Kabupaten Kudus senada dengan riset Widhiastuti dan Fachrurozie (2014), Yudianto, Sumardi, dan Berman (2014), Cahyaningsih (2017), Prasetiyaningsih, Kanzunnudin, dan Ismaya (2017), Setyowati (2017), serta Hikmah, Anwar, dan Riyanto (2018). Adapun perbedaan penelitian yang dilakukan dengan riset tersebut diatas yaitu pada pemilihan media, subyek penelitian, serta lokasi penelitian.

Berdasarkan latar belakang diatas maka rumusan masalah pada penelitian ini yaitu (1) Bagaimana peningkatan keterampilan mengajar guru dengan diterapkannya model pembelajaran Team Games Tournament berbantuan media Pemprof pada tema Berbagai Pekerjaan muatan IPS dan Bahasa Indonesia siswa kelas IV SD 5 Lau?. (2) Bagaimana peningkatan hasil belajar siswa dengan diterapkannya model pembelajaran Team Games Tournament berbantuan media Pemprof pada tema Berbagai Pekerjaan muatan IPS dan Bahasa Indonesia siswa kelas IV SD 5 Lau?.

\section{METODE PELAKSANAAN}

Penelitian ini merupakan penelitian tindakan kelas (PTK) yang dilaksanakan dalam dua siklus, setiap siklus terdiri dari empat tahap yakni perencanaan, pelaksanaan, observasi dan refleksi. Lokasi penelitian di SD 5 Lau yang beralamat di Desa Lau RT 05/RW 05 Kecamatan Dawe Kabupaten Kudus. Subjek penelitian yaitu siswa kelas IV SD 5 Lau semester I tahun ajaran 2019/2020 yang berjumlah 16 siswa, terdiri dari delapan orang siswa laki laki dan delapan orang siswa perempuan.

Sumber data dari penelitian ini yaitu guru dan siswa. Teknik pengumpulan data meliputi teknik wawancara, observasi, tes, dan dokumentasi. Validitas data yang digunakan yaitu Expert Judgement dengan menggunakan teknik analisis data kualitatif dan kuantitatif. Indikator keberhasilan dalam penelitian ini yakni 1) keterampilan guru memperoleh skor minimal 75 dengan persentase $\geq 75 \%$ dengan kriteria penilaian baik, 2) hasil belajar siswa ranah pengetahuan yaitu tercapainya nilai KKM yakni untuk muatan IPS 70 dan muatan Bahasa Indonesia 75 dengan ketuntasan klasikal $\geq 75 \%$ dengan kriteria tinggi. Sedangkan untuk keterampilan siswa mencapai persentase $\geq 75 \%$ dengan kriteria tinggi.

\section{HASIL DAN PEMBAHASAN}

Penelitian tindakan kelas dilakukan dengan persetujuan guru kelas IV SD 5 Lau dengan waktu pelaksanaan siklus I pada tanggal 4-5 November 2019 dan siklus II dilaksanakan pada tanggal 11-12 November 2019.

\section{Siklus I}

\section{a. Perencanaan}

Perencanaan ini dimaksudkan agar dalam pelaksanaan pembelajaran dapat berjalan dengan baik dan dapat mencapai tujuan pembelajaran yang diharapkan. Kegiatan perencanaan dalam penelitian siklus I berupa 1) penyusunan silabus dan Rencana Pelaksanaan Pembelajaran (RPP), 2) penentuan waktu pelaksanaan penelitian siklus I bersama guru kelas, 3) mempersiapkan sumber dan media pembelajaran. Dalam penelitian ini media yang digunakan yaitu media Pemprof. Peneliti mempersiapkan permainan, kartu soal, bidak, dan dadu, 4) menyiapkan instrumen penelitian berupa lembar pengamatan siswa dan guru.

\section{b. Pelaksanaan}

Tahap kedua dari penelitian tindakan ini yakni pelaksanaan. Penelitian dilaksanakan dengan menerapkan model pembelajaran Team Games Tournament berbantuan media Pemprof untuk meningkatkan hasil belajar siswa kelas IV SD 5 Lau pada tema 4 Berbagai Pekerjaan.

Penelitian siklus I pertemuan 1 dilaksanakan hari Senin 4 November 2019 pukul 07.30-10.05 WIB dengan alokasi waktu $4 \times 35$ menit. Adapun materi yang diajarkan yaitu kegiatan ekonomi dan menilai tokoh yang terdapat dalam teks cerita. Pada tahap pelaksanaan, terdapat tiga kegiatan yaitu kegiatan pendahuluan, kegiatan inti, dan kegiatan penutup.

Kegiatan pendahuluan berupa kegiatan guru untuk mengondisikan kelas, membuka pembelajaran dengan salam dan berdoa, menyanyikan lagu "Indonesia Raya", mengecek kehadiran siswa, serta menyampaikan tujuan pembelajaran. Kegiatan selanjutnya yakni pelaksanaan langkah-langkah model pembelajaran Team Games Tournament. Adapun langkah-langkah TGT meliputi 1) Class Presentation (Kelas Presentasi), 2) Team (Tim), 3) Games (Permainan), 4) Tournament (Turnamen), dan 5) Team Recognition (Rekognisi Tim).

Kegiatan penutup diawali guru dengan tindakan refleksi dan memberikan penguatan (reinforcement). Ketika kegiatan penguatan siswa pun terlihat mendengarkan dengan seksama dan setelah itu siswa berdoa untuk mengakhiri pembelajaran. Kegiatan penutup 


\section{PENERAPAN MODEL TEAM GAMES TOURNAMENT BERBANTUAN MEDIA PEMPROF UNTUK MENINGKATKAN HASIL BELAJAR SISWA KELAS IV SEKOLAH DASAR}

JURNAL PRASASTI ILMU Volume 1 Nomor 1 hlm. 1 - 12

berjalan dengan lancar tanpa ditemukan adanya siswa melanggar peraturan.

Penelitian siklus I pertemuan 2 dilaksanakan hari Selasa, 5 November 2019 pukul 07.00-09.35 WIB dengan alokasi waktu $4 \times 35$ menit. Siklus I pertemuan 2 merupakan kelanjutan dari siklus I pertemuan 1. Pada siklus I pertemuan 2 materi yang disampaikan yakni mengenai teks cerita dan cara menjaga kelestarian lingkungan. Pembelajaran pada siklus 1 pertemuan 2 mengacu pada Rencana Pelaksanaan Pembelajaran (RPP) yang telah dibuat yakni kegiatan pendahuluan, kegiatan inti, dan kegiatan penutup.

Pembelajaran pada siklus I pertemuan 2 diawali dengan kegiatan pendahuluan. Guru membuka pembelajaran dengan salam dan berdoa, menyanyikan lagu "Satu Nusa Satu Bangsa", dan mengecek kehadiran siswa. Kegiatan selanjutnya yakni pelaksanaan langkah-langkah model pembelajaran Team Games Tournament. Adapun langkah-langkah TGT meliputi 1) Class Presentation (Kelas Presentasi), 2) Team (Tim), 3) Games (Permainan), 4) Tournament (Turnamen), dan 5) Team Recognition (Rekognisi Tim). Pada kegiatan penutup siswa terlebih dahulu mengerjakan soal tes evaluasi yang diberikan guru. Siswa mengerjakan soal tes evaluasi dengan tenang. Setelah mengerjakan soal tes kemudian siswa bersama guru melakukan refleksi dan guru pun memberikan penguatan. Setelah itu siswa kemudian berdoa untuk mengakhiri pembelajaran dan siswa terlihat dapat mengikuti kegiatan penutup dengan tenang dan tertib.

\section{c. Observasi}

Pada tahap observasi, dilakukan pengamatan terhadap keterampilan mengajar guru dan hasil belajar siswa ranah keterampilan. Data dikumpulkan peneliti dengan menggunakan lembar observasi keterampilan mengajar guru dan lembar observasi hasil belajar siswa ranah keterampilan. Pengambilan data keterampilan mengajar dilakukan oleh guru kelas IV SD 5 Lau (Subiyanto, S.Pd). Sedangkan untuk mengamati hasil belajar siswa ranah keterampilan dan pengambilan dokumentasi, peneliti dibantu oleh teman sejawat yaitu Moh. Luqman Hakim.

\section{Keterampilan Guru} guru pada siklus I

Tabel 1. Hasil Observasi Keterampilan Mengajar Guru Siklus

\begin{tabular}{|c|c|c|c|c|}
\hline No. & Siklus & Total Skor & Persentase & Kualifikasi \\
\hline 1. & Siklus I Pertemuan 1 & 72 & $72 \%$ & Baik \\
\hline 2. & Siklus I Pertemuan 2 & 79 & $79 \%$ & Baik \\
\hline \multicolumn{2}{|c|}{ Rata-rata Siklus I } & 76 & $76 \%$ & Baik \\
\hline
\end{tabular}

(Sumber: Data Observasi Siklus 1 Tanggal 4-5 November 2019)

Berdasarkan tabel 1 diketahui bahwa keterampilan mengajar guru siklus I pertemuan 1 memperoleh skor 72 dengan persentase $71 \%$ serta dalam kriteria baik. Sedangkan siklus I pertemuan 2 mendapatkan skor 79 dengan persentase $79 \%$ serta dalam kriteria baik. Jika dirata-rata maka hasil keterampilan mengajar guru siklus I memperoleh skor 76 dengan persentase $76 \%$ serta dalam kriteria baik. Pada siklus I sudah mulai terlihat peningkatan keterampilan mengajar guru yang berarti guru mau dan mampu untuk berinovasi serta percaya diri dalam melaksanakan pembelajaran.

\section{Hasil Belajar Siswa Ranah Pengetahuan}

Hasil belajar siswa ranah pengetahuan pada siklus I diketahui dari hasil soal tes evaluasi yang berjumlah sepuluh soal (lima soal muatan IPS dan lima soal muatan Bahasa Indonesia). Tes evaluasi siklus I dilaksanakan pada Selasa, 5 November 2019. Berdasarkan hasil tes evaluasi diketahui bahwa hasil belajar ranah pengetahuan pada siklus I muatan IPS memperoleh nilai rata-rata 76,25 dengan nilai tertinggi 90 dan nilai terendah 60. Pada siklus I muatan IPS diketahui siswa yang tuntas sebanyak 12 orang dan siswa yang tidak tuntas sebanyak empat orang. Dengan demikian dapat diketahui bahwa persentase ketuntasan klasikal hasil belajar siklus I muatan IPS yakni $75 \%$ dengan kriteria tinggi.

Hasil belajar ranah pengetahuan siklus I muatan Bahasa Indonesia diketahui bahwa memperoleh nilai rata-rata 73,12 dengan nilai tertinggi 90 dan nilai terendah 45. Pada siklus I muatan Bahasa Indonesia diketahui siswa yang tuntas sebanyak sembilan orang dan siswa yang tidak tuntas sebanyak tujuh orang. Dengan demikian dapat diketahui bahwa persentase ketuntasan klasikal hasil belajar siklus I muatan Bahasa Indonesia yakni 56,25\% dengan kriteria sedang.

Berdasarkan data penelitian maka 

MENINGKATKAN HASIL BELAJAR SISWA KELAS IV SEKOLAH DASAR

JURNAL PRASASTI ILMU Volume 1 Nomor $1 \mathrm{hlm} .1$ - 12

hasil belajar ranah pengetahuan siklus I muatan IPS sudah mencapai indikator keberhasilan, sedangkan untuk muatan Bahasa Indonesia belum mencapai indikator keberhasilan. Indikator keberhasilan dalam penelitian ini yakni ketuntasan klasikal sebesar $75 \%$. Untuk lebih jelasnya persentase hasil belajar siklus I dapat dilihat pada diagram dibawah.

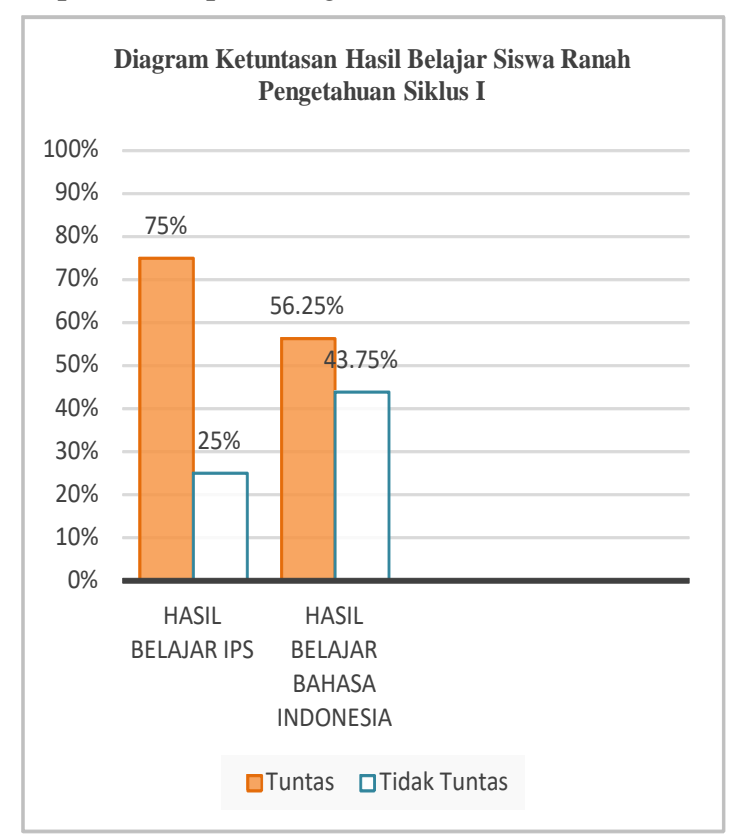

Gambar 1. Diagram Ketuntasan Hasil Belajar Ranah Pengetahuan Siklus I

(Sumber: Data Observasi Siklus I tanggal 5 November 2019)

\section{Hasil Belajar Ranah Keterampilan}

Hasil belajar siswa ranah keterampilan pada penelitian ini meliputi enam aspek yaitu mengamati, menanya, mencoba, menalar, menyaji dan mencipta. Hasil belajar tersebut didapat dengan melakukan kegiatan observasi yang dilakukan selama penelitian siklus I pertemuan 1 dan 2 dengan bantuan teman sejawat. Berdasarkan data penelitian diketahui bahwa hasil belajar siswa ranah keterampilan pada siklus I pertemuan 1 memperoleh persentase $68,49 \%$ dengan kriteria baik. Skor tertinggi yakni 21 dan skor terendah sebesar 12. Sedangkan pada siklus I pertemuan 2 diperoleh persentase sebesar 72,66\% dengan kriteria baik. Skor tertinggi yakni 21 dan skor terendah sebesar 13. Jika dirata-rata maka hasil belajar siswa ranah keterampilan pada siklus I sebesar 70,57\% dengan kriteria baik. Hasil belajar siswa ranah keterampilan sebesar $70,57 \%$ masih belum memenuhi indikator keberhasilan yang ditetapkan dalam penelitian yakni $\geq 75 \%$. Oleh karena itu untuk mencapai hasil yang lebih baik maka penelitian dilanjutkan pada siklus II dengan harapan dapat mencapai hasil yang lebih baik.

\section{d. Refleksi}

Pada tahap ini peneliti bersama observer melakukan refleksi untuk mengetahui hasil siklus I yang kemudian dicari solusinya dengan tujuan dapat diperbaiki pada siklus II. Berikut hasil refleksi siklus I antara lain 1) keterampilan mengajar guru pada siklus I yang sudah menunjukkan peningkatan masih harus diperbaiki lagi supaya lebih berkualitas pada siklus II, 2) hasil belajar siswa ranah pengetahuan muatan Bahasa Indonesia pada siklus I belum menacapai indikator keberhasilan sehingga harus diperbaiki supaya meningkat, 3) rata-rata hasil belajar ranah keterampilan pada siklus I sebesar 70,59\% belum mencapai indikator keberhasilan yaitu $\geq 75 \%$ sehingga harus diperbaiki, 4) masih ada siswa yang tidak mendengarkan ketika dijelaskan, sering kali keluar dari tempat duduknya, tidak mau berkelompok dan siswa yang asyik bermain atau mengobrol dengan temannya saat pembelajaran.

Berdasarkan pada refleksi siklus I maka peneliti melanjutkan penelitian ke siklus II. Pada siklus II peneliti berharap dapat memperbaiki kesalahan dan dapat meningkatkan hasil belajar ranah pengetahuan dan keterampilan serta dapat meningkatkan keterampilan mengajar guru.

\section{Siklus II}

\section{a. Perencanaan}

Penelitian siklus II diawali dengan membuat perencanaan yang didasarkan pada hasil dan temuan siklus I. Perencanaan ini dimaksudkan agar dalam pelaksanaan pembelajaran dapat berjalan dengan baik dan dapat meningkatkan hasil pada siklus II agar tercapai tujuan yang telah ditetapkan. Kegiatan perencanaan dalam penelitian siklus II berupa menyiapkan silabus dan RPP, menentukan waktu penelitian, menyiapkan materi dan soal serta lembar observasi keterampilan guru dan lembar observasi hasil belajar siswa ranah keterampilan.

\section{b. Pelaksanaan}

Penelitian siklus II dilakasanakan pada tanggal 11-12 November 2019. Pelaksanaan II merupakan tindak lanjut dari penelitian siklus I. Penelitian siklus II pertemuan I dilaksanakan pada Senin, 11 November 2019 pukul 07.3010.05 WIB dengan alokasi waktu $4 \times 35$ menit. Adapun materi yang diajarkan pada siklus II pertemuan 1 yaitu mengidentifikasi tokoh dalam sebuah teks cerita dan penerapan nilai sila pertama Pancasila. 


\section{PENERAPAN MODEL TEAM GAMES TOURNAMENT BERBANTUAN MEDIA PEMPROF UNTUK MENINGKATKAN HASIL BELAJAR SISWA KELAS IV SEKOLAH DASAR}

JURNAL PRASASTI ILMU Volume 1 Nomor $1 \mathrm{hlm} .1$ - 12

Kegiatan pendahuluan pada siklus II pertemuan 1 diawali dengan guru mengondisikan kelas, membuka pembelajaran dengan salam dan berdoa bersama, kemudian dilanjutkan dengan menyanyikan lagu "Indonesia Raya", mengecek kehadiran siswa dan dilanjutkan dengan menyampaikan tujuan pembelajaran. Kegiatan selanjutnya yakni pelaksanaan langkah-langkah model pembelajaran Team Games Tournament. Adapun langkah-langkah TGT meliputi 1) Class Presentation (Kelas Presentasi), 2) Team (Tim), 3) Games (Permainan), 4) Tournament (Turnamen), dan 5) Team Recognition (Rekognisi Tim).

Kegiatan penutup diawali guru dengan tindakan refleksi dan memberikan penguatan (reinforcement). Ketika kegiatan penguatan siswa pun terlihat mendengarkan dengan seksama dan setelah itu siswa berdoa untuk mengakhiri pembelajaran. Kegiatan penutup berjalan dengan lancar tanpa ditemukan adanya siswa melanggar peraturan.

Penelitian siklus II pertemuan 2 dilaksanakan pada Selasa, 12 November 2019 pukul 07.00-09.35 WIB dengan alokasi waktu $4 \times 35$ menit. Siklus II pertemuan 2 merupakan kelanjutan dari siklus II pertemuan 1. Pada siklus II pertemuan 2 materi yang disampaiakan yakni macam-macam pekerjaan dan mengambar jenis pekerjaan. pembelajaran pada siklus II pertemuan 2 mengacu pada Rencana Pelaksanaan Pembelajaran (RPP) yang telah dibuat yang meliputi kegiatan pendahuluan, kegiatan inti dan kegiatan penutup.

Pembelajaran pada siklus II pertemuan 2 diawali dengan kegiatan pendahuluan, guru memulai kegiatan pendahuluan dengan salam. Siswa kemudian berdoa bersama, pada saat kegiatan berdoa terlihat semua siswa sudah dapat mengikuti kegiatan berdoa dengan baik. Selanjutnya siswa menyanyikan lagu "Bagimu Negeri", saat menyanyikan lagu keseluruhan siswa juga sudah mau menyanyi dengan baik

Tabel 2. Hasil Observasi Keterampilan Mengajar Guru Siklus II

\begin{tabular}{|c|c|c|c|c|}
\hline No. & Siklus & Total Skor & Persentase & Kualifikasi \\
\hline 1. & Siklus II Pertemuan 1 & 84 & $84 \%$ & Sangat Baik \\
\hline 2. & Siklus II Pertemuan 2 & 87 & $87 \%$ & Sangat Baik \\
\hline \multicolumn{2}{|c|}{ Rata-rata Siklus II } & $\mathbf{8 5 , 5}$ & $\mathbf{8 5 , 5 \%}$ & Sangat Baik \\
\hline
\end{tabular}

(Sumber: Data Observasi Siklus II tanggal 11-12 November 2019)

Berdasarkan tabel 2 diketahui bahwa hasil observasi keterampilan mengajar guru pada siklus II pertemuan 1 diperoleh skor 84 dengan persentase $84 \%$ serta dalam kriteria Sangat Baik, sedangkan pada siklus II dan benar. Setelah itu guru mengecek kehadiran siswa dan dilanjutkan dengan siswa mendengarkan penjelasan guru mengenai tujuan dari kegiatan pembelajaran pada hari itu.

Pembelajaran pada siklus I pertemuan 2 diawali dengan kegiatan pendahuluan. Guru membuka pembelajaran dengan salam dan berdoa, menyanyikan lagu "Satu Nusa Satu Bangsa", dan mengecek kehadiran siswa. Kegiatan selanjutnya yakni pelaksanaan langkah-langkah model pembelajaran Team Games Tournament. Adapun langkah-langkah TGT meliputi 1) Class Presentation (Kelas Presentasi), 2) Team (Tim), 3) Games (Permainan), 4) Tournament (Turnamen), dan 5) Team Recognition (Rekognisi Tim).

Pada kegiatan penutup siswa terlebih dahulu mengerjakan soal tes evaluasi yang diberikan guru. Siswa mengerjakan soal tes evaluasi dengan tenang. Setelah mengerjakan soal tes kemudian siswa bersama guru melakukan refleksi dan guru pun memberikan penguatan. Setelah itu siswa kemudian berdoa untuk mengakhiri pembelajaran dan siswa terlihat dapat mengikuti kegiatan penutup dengan tenang dan tertib.

\section{c. Observasi}

Pada tahap observasi, dilakukan pengamatan terhadap keterampilan mengajar guru dan hasil belajar siswa ranah keterampilan. Data dikumpulkan peneliti dengan menggunakan lembar observasi keterampilan mengajar guru dan lembar observasi hasil belajar siswa ranah keterampilan. Pengambilan data keterampilan mengajar dilakukan oleh guru kelas IV SD 5 Lau (Subiyanto, S.Pd). Sedangkan untuk mengamati hasil belajar siswa ranah keterampilan dan pengambilan dokumentasi, peneliti dibantu oleh teman sejawat.

\section{Keterampilan Guru}

Berikut data observasi keterampilan guru pada siklus I pertemuan 2 skor total yang diperoleh 87 dengan persentase $87 \%$ dengan kriteria sangat baik. Jika dirata-rata maka hasil keterampilan guru pada siklus II memperoleh persentase sebesar $85,5 \%$ dengan kriteria sangat baik. 


\section{PENERAPAN MODEL TEAM GAMES TOURNAMENT BERBANTUAN MEDIA PEMPROF UNTUK} MENINGKATKAN HASIL BELAJAR SISWA KELAS IV SEKOLAH DASAR

JURNAL PRASASTI ILMU Volume 1 Nomor $1 \mathrm{hlm} .1$ - 12

\section{Hasil Belajar Siswa Ranah Pengetahuan}

Hasil belajar siswa ranah pengetahuan pada siklus II diketahui dari hasil tes evaluasi yang berjumlah 10 soal ( 5 soal muatan IPS dan 5 soal muatan Bahasa Indonesia). Soal tes evaluasi diberikan pada akhir siklus II yaitu pertemuan 2 pada hari Selasa, 12 November 2019. Berdasarkan hasil tes evaluasi diketahui bahwa hasil belajar ranah pengetahuan siklus II untuk muatan IPS memperoleh nilai rata-rata 77,5 dengan nilai tertinggi 90 dan nilai terendah 55. Pada siklus II muatan IPS diketahui siswa yang tuntas sebanyak 13 orang dan yang tidak tuntas sebanyak tiga orang. Dengan demikian dapat diketahui bahwa persentase ketuntasan klasikal hasil belajar ranah pengetahuan siklus II muatan IPS adalah $81,25 \%$ dengan kriteria sangat tinggi.

Hasil belajar ranah pengetahuan siklus II muatan Bahasa Indonesia memperoleh ratarata 84,06 dengan nilai tertinggi 95 dan nilai terendah 50. Pada siklus II muatan Bahasa Indonesia diketahui siswa yang tuntas sebanyak 13 orang dan siswa yang tidak tuntas sebanyak tiga orang. Dengan demikian dapat diketahui bahwa persentase ketuntasan klasikal hasil belajar ranah pengetahuan siklus II muatan Bahasa Indonesia adalah $81,25 \%$ dengan kriteria sangat tinggi.

Hal ini menunjukkan bahwa hasil belajar ranah pengetahuan siklus II muatan IPS dan Bahasa Indonesia sudah mencapai indikator keberhasilan. Indikator keberhasilan dalam penelitian ini adalah ketuntasan klasikal sebesar $75 \%$.

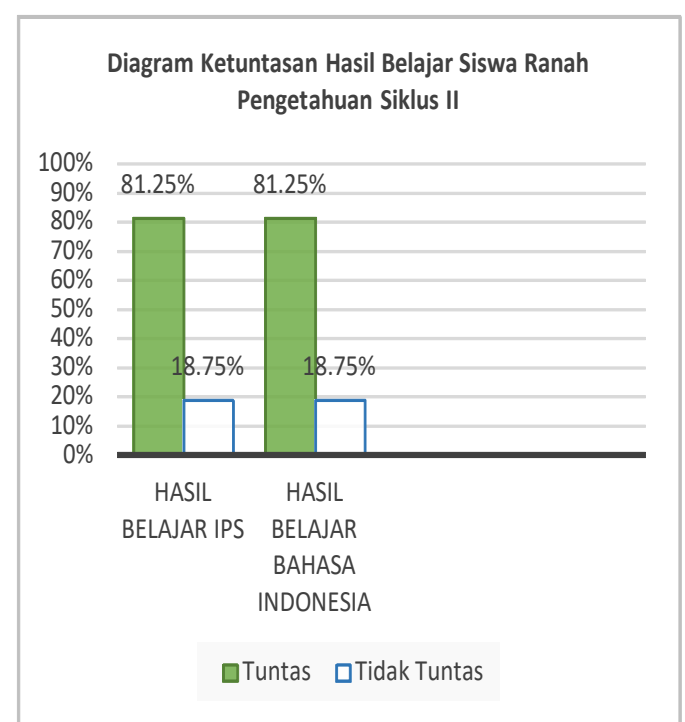

Gambar 2. Diagram Ketuntasan Hasil Belajar Ranah Pengetahuan Siklus II

(Sumber: Data Observasi Siklus II tanggal 12 November 2019)

\section{Hasil Belajar Siswa Ranah Keterampilan}

Hasil belajar siswa ranah keterampilan pada penelitian ini meliputi 6 aspek yaitu Mengamati, Menanya, Mencoba, Menalar, Menyaji dan mencipta. Hasil belajar tersebut didapat dengan melakukan kegiatan observasi yang dilakukan selama penelitian siklus I yang mencakup pertemuan 1 dan 2 dengan bantuan teman sejawat.

Berdasarkan data penelitian dapat diketahui bahwa hasil belajar siswa ranah keterampilan pada siklus II pertemuan 1 memperoleh persentase $79,95 \%$ dengan kriteria baik. Skor tertinggi untuk hasil belajar ranah keterampilan siklus II pertemuan 1 yakni 22 dan skor terendah yakni 16. Sedangkan pada siklus II pertemuan 2 diperoleh persentase sebesar $80,21 \%$ dengan kriteria baik. Skor tertinggi untuk hasil belajar siswa ranah keterampilan siklus II pertemuan 2 yakni 21 dan skor terendah yakni 16. Jika dirata-rata maka hasil belajar siswa ranah keterampilan pada siklus II sebesar 80,08\% dengan kriteria baik.

Dari data penelitiant diketahui bahwa rata-rata persentase hasil belajar siswa ranah keterampilan siklus II mengalami peningkatan dari siklus I. Pada siklus II rata-rata persentasenya yaitu sebesar 80,08\% dan hasil tersebut telah memenuhi indikator keberhasilan yang ditetapkan dalam penelitian ini yakni $\geq$ $75 \%$.

\section{d. Refleksi}

Tahap keempat dari penelitian tindakan kelas siklus II yaitu refleksi. Refleksi diadakan berdasarkan observasi dari kegiatan yang telah dilakukan observer pada penelitian siklus II. Berdasarkan data penelitian siklus II, diperoleh data hasil keterampilan guru mengajar pada siklus II pertemuan 1 sebesar $84 \%$ dengan kategori sangat baik dan pada siklus II pertemuan 2 mengalami peningkatan sebesar $87 \%$ dengan kategori sangat baik. Jika dirata-rata maka pada siklus II hasil keterampilan guru memperoleh persentase sebesar 85,5\% dengan kategori sangat baik.

Untuk hasil belajar siswa ranah pengetahuan siklus II nilai rata-rata muatan IPS yakni 77,5 dengan siswa yang tuntas sebanyak 13 orang dengan persentase ketuntasan $81,25 \%$ dan untuk muatan Bahasa Indonesia yakni 84,06 dengan siswa yang tuntas sebanyak 13 orang dengan persentase ketuntasan $81,25 \%$. Dari hasil tersebut dapat disimpulkan bahwa hasil belajar siswa pada ranah pengetahuan untuk muatan IPS dan Bahasa Indonesia sudah mencapai indikator keberhasilan yaitu $\geq 75 \%$ 


\section{PENERAPAN MODEL TEAM GAMES TOURNAMENT BERBANTUAN MEDIA PEMPROF UNTUK MENINGKATKAN HASIL BELAJAR SISWA KELAS IV SEKOLAH DASAR}

JURNAL PRASASTI ILMU Volume 1 Nomor $1 \mathrm{hlm} .1$ - 12

dari jumlah siswa.

Selanjutnya yakni hasil belajar ranah keterampilan. Diketahui pada siklus II pertemuan 1 memperoleh persentase $79,95 \%$ dengan kategori baik dan untuk pertemuan 2 memperoleh 80,21\% dengan kategori baik. Jika dirata-rata maka hasil belajar ranah pengetahuan siklus I sebesar 80,08\%. Hal tersebut menunjukkan bahwa hasil belajar ranah keterampilan sudah mencapai indikator keberhasilan yaitu $\geq 75 \%$.

Berdasarkan dari data yang telah diperoleh pada siklus II dapat disimpulkan bahwa penelitian yang dilakukan sudah mencapai hasil dari indikator keberhasilan yang sebelumnya telah ditetapkan. Oleh karena itu, penelitian dengan menerapkan model Team Games Tournament berbantuan media Pemprof untuk meningkatkan hasil belajar siswa pada tema 4 kelas IV SD 5 Lau dilakukan sebanyak 2 siklus karena pada siklus kedua indikator keberhasilan sudah tercapai.

Hasil penelitian tindakan kelas yang telah dilakukan perlu dianalisa lebih lanjut sehingga menjadi jelas dan bermakna. Oleh karena pada bagian berikut disajikan analisa terhadap keterampilan guru, hasil belajar siswa ranah pengetahuan dan hasil belajar siswa ranah keterampilan.

\section{Keterampilan Guru}

Penilaian keterampilan guru dalam mengajar pada riset ini berlandaskan pada pendapat Turney (dalam Majid 2013) yang meliputi delapan keterampilan mengajar guru yaitu (1) keterampilan bertanya, (2) keterampilan memberi penguatan, (3) keterampilan mengajar kelompok kecil dan perorangan, (4) keterampilan menjelaskan, (5) keterampilan membuka dan menutup pelajaran, (6) keterampilan membimbing diskusi kelompok kecil, (7) keterampilan mengelola kelas, dan (8) keterampilan mengadakan variasi.

Hasil riset siklus I menunjukkan bahwa masih terdapat kekurangan dalam proses pembelajaran yakni pada keterampilan mengelola kelas. Guru masih kesulitan dalam menguasai kelas sehingga siswa masih banyak yang ramai dan tidak memerhatikan guru. Padahal agar pembelajaran dapat berlangsung secara optimal guru harus mampu mengelola kelas dengan baik. Turney (dalam Majid, 2013) mengemukakan bahwa keterampilan megelola kelas mencakup keterampilan yang berhubungan dengan penciptaan dan pemeliharaan serta pengendalian kondisi belajar yang optimal. Seperti yang dikemukakan oleh Darmadi (2012) bahwa tujuan mengelola kelas yaitu agar semua siswa yang ada di dalam kelas dapat belajar dengan optimal dan mengatur sara pembelajaran serta mengendalikan suasana belajar yang menyenangkan untuk mencapai tujuan belajar. pengelolaan kelas sangatlah penting karena dengan pengelolaan yang baik tujuan pembelajaran akan tercapai.

Kekurangan berikutnya yaitu terdapat pada keterampilan memberikan penguatan yang mengakibatkan siswa kurang terdorong untuk memerhatikan pembelajaran. Turney (dalam Majid, 2013) menyebut bahwa seorang guru harus menguasai keterampilan memberikan penguatan karena penguatan merupakan dorongan bagi siswa untuk meningkatkan perhatian. Kemampuan memberikan penguatan perlu dikuasai guru agar siswa mendapat motivasi belajar sehingga siswa tersebut dapat mengikuti pembelajaran dengan sungguh-sungguh. Salah satu tujuan dari penggunaan penguatan adalah seperti yang dikemukakan Huda (2010:88) yaitu untuk meningkatkan perhatian siswa dalam proses belajar dan untuk membangkitkan, memelihara dan meningkatkan motivasi belajar siswa. Penguatan sangat penting dilakukan oleh guru agar proses pembelajaran dapat berjalan dengan lancar sehingga tujuan dari pembelajaran yang telah ditentukan dapat ditercapai.

Kekurangan selanjutnya yang perlu dibenahi yakni keterampilan dalam mengadakan variasi. Dalam hal ini guru kurang dalam mengajak siswa ikut aktif dalam kegiatan pembelajaran seperti megikutsertakan siswa dalam kegiatan pembelajaran seperti meminta siswa untuk berpendapat atau menyampaikan pendapatnya. Huda (2010:94) menyebutkan tujuan dari penggunaan variasi belajar salah satunya adalah untuk mengatasi dan mengurangi kejenuhan dalam proses pembelajaran. Variasi diperlukan agar siswa tidak bosan dan dapat menarik minat belajar siswa.

Kekurangan-kekurangan tersebut diperbaiki pada siklus II. Dengan memperbaiki cara mengajar dan dengan memaksimalkan pembelajaran dengan menerapkan model Team Games Tournament berbantuan media Pemprof. Kondisi yang terjadi setelah dilakukan perbaikan yakni dengan meningkatnya persentase keterampilan mengajar guru dan keadaan kelas yang semakin kondusif selama berlangsungnya kegiatan pembelajaran. keterampilan mengajar guru pada siklus II pertemuan 1 memperoleh persentase $84 \%$ dan pertemuan 2 dengn 


\section{PENERAPAN MODEL TEAM GAMES TOURNAMENT BERBANTUAN MEDIA PEMPROF UNTUK MENINGKATKAN HASIL BELAJAR SISWA KELAS IV SEKOLAH DASAR}

JURNAL PRASASTI ILMU Volume 1 Nomor 1 hlm. 1 - 12

persentase $87 \%$. Jika dirata-rata, maka persentase keterampilan mengajar guru pada siklus II adalah $85,5 \%$ dengan kualifikasi sangat baik.

Berdasarkan penjelasan tersebut dapat ditarik simpulan bahwa hipotesis tindakan yang diajukan telah terbukti dan indikator keberhasilan telah berhasil tercapai dengan memperoleh persentase rata-rata siklus II sebesar $85,5 \%$ (melebihi indikator keberhasilan yaitu $\geq 75 \%$ ). Hasil tersebut sejalan dengan penelitian Mulyati (2019) yang menerapkan model Team Games Tournament, diketahui keterampilan mengajar guru pada siklus I memperoleh 37 dengan kategori baik dan mengalami peningkatan pada siklus II dengan memperoleh skor 47 dengan kategori sangat baik.

\section{Hasil Belajar Siswa Ranah Pengetahuan}

Anderson dan Krathwohl (2010:99-

106) menyebutkan bahwa aspek pengetahuan dibagi menjadi 6 tingkatan yaitu mengingat (C1), memahami (C2), menerapkan (C3), menganalisis (C4), mengurai (C5), mencipta (C6). Berdasarkan data penelitian diketahui bahwa masalah yang ditemukan dalam siklus I diantaranya yakni siswa yang masih tidak mendengarkan ketika dijelaskan, siswa yang sering kali keluar dari tempat duduknya, siswa yang tidak mau berkelompok dan siswa yang asyik bermain atau mengobrol dengan temannya saat pembelajaran.

Untuk mengatasi hal tersebut guru akan menerapkan sistem denda. Yaitu guru memberikan koin kepada masing-masing kelompok kemudian guru bersama siswa membuat kesepakatan tentang hal yang harus dilakukan selama pembelajaran yakni siswa harus mendengarkan penjelasan dari guru, siswa tidak boleh keluar dari tempat duduknya atau keluar dari ruangan tanpa izin dari guru, dan siswa harus ikut membantu dalam berkelompok dan tidak boleh bermain sendiri atau mengobrol dengan temannya yang lain. jika siswa melanggar maka siswa akan dikenai denda yaitu koin kelompok mereka akan diminta lagi oleh guru.

Jamaris (2014) berpendapat bahwa kesulitan perhatian mencangkup kesulitan dalam memusatkan perhatian adalah kesulitan dalam memfokuskan perhatian pada suatu kegiatan dan kesulitan dalam menghentikan perhatian. Penanganan permasalahan dalam kesulitan belajar harus dilakukan dengan baik sehingga guru mampu membantu siswa dalam mengatasi kesulitan belajarnya. Seperti pendapat Subini (2011) salah satu cara yang dapat dilakukan untuk mengatasi kesulitan belajar anak adalah dengan memberikan penanganan yang baik. penangan tersebut dapat berupa pemberian motivasi. Setelah motivasi mulai timbul pada diri siswa, maka peran aktif siswa terhadap pembelajaran juga meningkat. Darmadi (2009) motivasi merupakan salah satu faktor penunjang keberhasilan siswa dalam belajar dan secara otomatis juga menunjang keberhasilan guru dalam mengelola proses pembelajaran, diharapkan pembelajaran anak lebih optimal.

Penelitian lain yang membuktikan bahwa penerapan model pembelajaran Team Games Tournament dapat meningkatkan hasil belajar ranah pengetahuan yakni riset Permatasari (2017) yang mencaatat bahwa hasil belajar ranah pengetahuan siklus I memperoleh rata-rata 57,8 dengan persentase ketuntasan klasikal $64,7 \%$ dan pada siklus II mengalami peningkatan dengan memperoleh rata-rata 73,64 dengan persentase ketuntasan klasikal $82,35 \%$

Secara umum, hasil belajar siswa dari mulai prasiklus, siklus I, dan siklus II mengalami peningkatan, hal itu dikarenakan guru sudah mampu menerapkan model pembelajaran Team Games Tournament dengan baik. Hal ini menunjukkan bahwa model Team Games Tournament berbantuan media Pemprof dapat meningkatkan hasil belajar siswa dan indikator keberhasilan telah tercapai yakni tercapainya ketuntasan klasikal $\geq 75 \%$.

\section{Hasil Belajar Siswa Ranah \\ Keterampilan}

Hasil belajar ranah keterampilan adalah hasil belajar yang nampak dalam bentuk keterampilan. Sudjana (2014) mengemukakan bahwa hasil belajar psikomotorik tampak dalam bentuk keterampilan (skill) dan kemampuan bertindak individu. pada penelitian ini terdapat enam aspek penilaian hasil belajar ranah keterampilan. Keenam aspek penilaian tersebut mengacu pada ranah olahan Dyers (dalam Priyatni, 2012) yang meliputi mengamati, menanya, mencoba, menalar, menyaji, dan mencipta. Aspek keterampilan ini berkaitan dengan kemampuan siswa dalam menerima dan menerapkan pembelajaran dengan berkelompok.

Aspek yang pertama yaitu mengamati. Menurut Dyers (2014) mengamati merupakan perhatian waktu mengamati suatu objek/membaca tulisan/mendengar penjelasan, catatan yang dibuat tentang diamati, kesabaran, 


\section{PENERAPAN MODEL TEAM GAMES TOURNAMENT BERBANTUAN MEDIA PEMPROF UNTUK MENINGKATKAN HASIL BELAJAR SISWA KELAS IV SEKOLAH DASAR}

JURNAL PRASASTI ILMU Volume 1 Nomor 1 hlm. 1 - 12

waktu yang digunakan untuk mengamati. Aspek mengamati dapat dilihat pada kegiatan saat siswa mendengarkan atau memperhatikan guru saat guru sedang menjelaskan. Aspek mengamati pada siklus I memperoleh rata-rata $81,25 \%$ dengan kategori baik kemudian meningkat menjadi $93,75 \%$ dengan kategori sangat baik. Hasil tersebut sejalan dengan penelitian Wilujeng (2013) dengan menerapkan model TGT hasil belajar ranah keterampilan pada aspek mengamati mengalami peningkatan dari yang awalnya pada siklus I diperoleh persentase rata-rata $68,75 \%$ meningkat di siklus II menjadi 78,54\%.

Aspek yang kedua yakni menanya. Keterampilan dalam aspek menaya berkaitan dengan jenis, kualitas, dan jumlah pertanyaan yang diajukan siswa (Dyers, 2014). Aspek menanya dapat dilihat pada saat pembelajaran berlangsung, yakni ketika siswa mengajukan pertanyaan. Pada siklus I aspek menanya memperoleh rata-rata $71,10 \%$ dengan kriteria baik dan meningkat pada siklus II menjadi $85,93 \%$ dengan kriteria sangat baik. Hal ini seperti pada penelitian Purba (2018) diketahui aktivitas siswa dalam menanya pada siklus I memperoleh rata-rata $10,53 \%$ kemudian meningkat di siklus II menjadi $36,84 \%$ dan pada siklus III meningkat menjadi $100 \%$.

Aspek yang ketiga yakni mencoba. Mencoba atau mengumpulkan informasi berkaitan dengan kualitas dan jumlah sumber yang dikaji, kelengkapan informasi yang dikumpulkan kemudian direalisasikan dalam bentuk tindakan (Dyers, 2014). Aspek mencoba dapat dilihat dari kesanggupan siswa dalam mempraktekkan arahan guru berdasarkan informasi yang mereka tangkap dari guru. pada siklus I aspek mencoba memperoleh rata-rata $73,44 \%$ dengan kriteria baik dan meningkat menjadi $76,56 \%$ dengan kriteria baik. Hal ini seperti yang terdapat pada penelitian Wilujeng (2013) hasil pada siklus I memperoleh rata-rata $69,27 \%$ dan rata-rata meningkat pada siklus II menjadi 78,41\%.

Aspek keempat yaitu menalar. Disebutkan Dyers (2014) bahwa menalar yaitu mengembangkan interpretasi, argumentasi, dan kesimpulan mengenai keterkaitan informasi dari dua fakta/konsep. Aspek menalar dapar dilihat saat siswa menyelesaikan tugas dari LKS maupun ketika permainan. Pada siklus I aspek menalar memperoleh persentase rata-rata $62,50 \%$ dengan kriteria baik dan pada siklus II memperoleh rata-rata $75,78 \%$ dengan kriteria baik. Hal tersebut sejalan dengan penelitian Mudrika dkk. (2018) yang memperoleh persentase rata-rata penilaian aspek menalar pada siklus I sebesar $72,4 \%$ dan mengalami peningkatan pada siklus II dengan persentase sebesar 78,6\%.

Aspek kelima yakni menyaji. Menurut Dyers (2014) menyaji merupakan mengomunikasikan hasil kajian dalam bentuk tulisan, grafis, media elektronik, multimedia, dll. Pada siklus I aspek menyaji memperoleh persentase rata-rata $69,53 \%$ dengan kriteria baik dan siklus II meningkat menjadi $74,22 \%$ dengan kriteria baik. Hal ini sejalan dengan penelitian Astuti dan Kristin (2017) yang memperoleh rata-rata siklus I $85,26 \%$ dan meningkat pada siklus II menjadi $96,15 \%$.

Aspek keenam yaitu mencipta. Mencipta merupakan kegiatan menghasilkan ide-ide, rancangan dan atau keputusan baru. Aspek mencipta dapat dilihat dari kemampuan siswa dalam menciptakan atau merangkai katakata. Pada siklus I tercatat persentase rata-rata aspek mencipta 64,06\% dengan kriteria baik dan meningkat pada siklus II 78,13\% dengan kategori baik. Hal ini menunjukkan bahwa terjadi penigkatan pada hasil belajar ranah keterampilan pada aspek mesncipta.

Hasil tersebut telah membuktikan bahwa hasil belajar siswa ranah keterampilan dapat meningkat dengan menerapkan model Team Games Tournament berbantuan media Pemprof dan indikator keberhasilan telah tercapai. Hasil tersebut sejalan dengan penelitian yang dilakukan oleh Khohar dkk (2016) dengan menyimpulkan bahwa penerapan model Team Games Tournament berbasis kearifan lokal berbantuan media Pemprof terbukti dapat meningkatkan hasil belajar siswa ranah keterampilan. Tercatat pada siklus I diperoleh persentase rata-rata $69,4 \%$ mengalami peningkatan pada siklus II menjadi $82,75 \%$

\section{KESIMPULAN}

Berdasarkan hasil penelitian tindakan kelas dan pembahasan maka dapat disimpulkan bahwa penerapan model Team Games Tournament berbantuan media Pemprof dapat meningkatkan hasil belajar siswa kelas IV SD 5 Lau pada tema berbagai pekerjaan muatan IPS dan Bahasa Indonesia.

Keterampilan mengajar guru pada tema berbagai pekerjaan muatan IPS dan Bahasa Indonesia mengalami peningkatan yaitu pada siklus I memperoleh skor rata-rata 76 dengan persentase sebesar $76 \%$ dengan kategori baik, persentase ini diperoleh karena guru dalam pembelajaran masih kurang menguasai kelas, kurangnya pengadaan variasi pembelajaran dan keterampilan memberikan 
Prisma Adi Putra, Erik Aditia Ismaya, Muhammad Noor Ahsin

\section{PENERAPAN MODEL TEAM GAMES TOURNAMENT BERBANTUAN MEDIA PEMPROF UNTUK MENINGKATKAN HASIL BELAJAR SISWA KELAS IV SEKOLAH DASAR}

JURNAL PRASASTI ILMU Volume 1 Nomor 1 hlm. 1 - 12

penguatan. Pada siklus II keterampilan mengajar guru meningkat dengan memperoleh skor rata-rata 85,5 dengan persentase $85,5 \%$ dengan kategori sangat baik dikarenakan guru telah mampu menguasai kelas dengan baik, mampu mengadakan variasi dalam pembelajaran dan mampu memberi penguatan kepada peserta didik dengan baik.

Hasil belajar siswa ranah pengetahuan pada tema berbagai pekerjaan muatan IPS mengalami peningkatan yaitu pada siklus I memperoleh nilai rata-rata 76,25 dengan persentase ketuntasan klasikal siswa $75 \%$ dengan kategori tinggi dan mengalami peningkatakan pada siklus II dengan nilai ratarata 77,5 dengan persentase ketuntasan klasikal siswa $81,25 \%$ dengan kategori sangat tinggi. Untuk hasil belajar siswa ranah pengetahuan pada tema berbagai pekerjaan muatan Bahasa Indonesia mengalami peningkatan yaitu pada siklus I memperoleh nilai rata-rata 73,12 dengan ketuntasan klasikal siswa 56,25\% dengan kategori sedang dan pada siklus II mengalami peningkatan dengan nilai rata-rata 84,06 dengan persentase ketuntasan klasikal siswa $81,25 \%$ dengan kategori sangat tinggi. Hasil belajar siswa ranah keterampilan mengalami peningkatan yaitu pada siklus I dengan rata-rata persentase mencapai $70,57 \%$ dengan kategori baik dan pada siklus II mengalami peningkatan dengan rata-rata persentase mencapai $80,08 \%$ dengan kategori baik.

\section{DAFTAR PUSTAKA}

Anderson, Lorin W. and David R. Krathwohl. 2010. Kerangka Landasan untuk Pembelajaran, Pengajaran, dan Asesmen: Revisi Taksonomi Pendidikan Bloom. Penerjemah: Agung Prihantoro. Yogyakarta: Pustaka Pelajar.

Ardianti, Sekar Dwi, Himmatul Ulya, dan Erik Aditia Ismaya. 2018. PAKEM dalam Kurikulum 2013. Kudus: Badan Penerbit Universitas Muria Kudus.

Astuti, Wahyu dan Firosalia Kristin. 2017. "Penerapan Model Pembelajaran Team Games Tournament untuk Meningkatkan Keaktifan dan IPA". Jurnal Ilmiah Sekolah Dasar 1.

Darmadi, Hamid. 2009. Kemampuan Dasar Mengajar. Pontianak: Alfabeta.

Hidayah, Lutfi Muslimatul. 2018. Penerapan Model Team Games Tournament (TGT)
Berbantuan Media Permainan Monopoli Untuk Meningkatkan Hasil Belajar PKn Siswa Kelas IV SDN 2 Kaliputu. Skripsi. Kudus: Universitas Muria Kudus.

Hikmah, Msy., Anwar, Yenny., dan Riyanto. 2018. Penerapan Model Pembelajaran Team Games Tournament (TGT) Terhadap Motivasi dan Hasil Belajar Peserta Didik Pada Materi Dunia Hewan kelas $\mathrm{X}$ di SMA Unggul Negeri 8 Palembang. Jurnal Pembelajaran Biologi, 5, (1).

Huda, Nurul. 2010. Strategi Pembelajaran. Jakarta: PT. Multi Kreasi Satudelapan.

Ibrahim, Muslimin. 2014. Pembelajaran Sains Di Sekolah Dasar Berbasis Kurikulum 2013. Premiere Educandum, 4 (1): 1-9.

Kemdikbud. 2018. Modul Pelatihan Kurikulum 2013. Jakarta: Kemdikbud.

Khohar, Moh. Adnan, Ruminiati, dan Munzil. 2016. "Penerapan Team Games Tournament untuk Meningkatkan Hasil Belajar IPS Kelas IV SDN Blabak Kediri”. Jurnal Pendidikan, 1 (9).

Kosasih, E. 2014. Strategi Belajar dan Pembelajaran Implementasi Kurikulum 2013. Bandung: Yrama Widya.

Krissandi, Apri Damai Sagita. 2018. Pengembangan Video Tematik Sebagai Pengantar Pembelajaran Kurikulum 2013 di Sekolah Dasar. Premiere Educandum: Jurnal Pendidikan Dasar dan Pembelajaran, 8 (1): 68 - 77.

Laksana, Dian. 2015. Penerapan Model Team Games Tournament (TGT) untuk Meningkatkan Kualitas Pembelajaran IPS Pada Siswa Kelas IV SD Negeri Dondong 01 Kabupaten Cilacap. Skripsi. Semarang: Universitas Negeri Semarang.

Majid, Abdul. 2013. Strategi Pembelajaran. Bandung: PT. Remaja Rosdakarya.

Mudrika, Muhammad Wijaya dan Sugiarti. 2018. "Penerapan Model Pembelajaran Kooperatif Tipe TGT untuk Meningkatkan Motivasi dan Aktivitas Belajar Peserta Didik Kelas X MIA 3 
SMAN 1 Tanete Rilau”. Jurnal Chemica, 19 (1).

Mulyati. 2019. "Peningkatan Kualitas Pembelajaran IPA Melalui Model Team Games Tournament (TGT) dengan Media Audiovisual Pada Siswa Kelas VI SD Negeri 3 Titiantui". Jurnal Pendidikan Tambusai, 3 (1).

Permatasari, Norhayati Endah. 2017 "Peningkatan Hasil Belajar IPA Siswa Kelas 5 SD Menggunakan Model Pembelajaran Kooperatif Tipe TGT Berbantuan Media Gambar". Jurnal Pendidikan Sekolah Dasar, 3 (2).

Permendikbud Nomor 104 Tahun 2014.

Prasetiyaningsih, Wahyu Dwi., Moh, Kanzunnudin., dan Ismaya, Erik Aditia. 2017. Penerapan Model Pembelajaran Teams Games Tournament Untuk Peningkatan Hasil Belajar Dalam Mata Pelajaran Ips Siswa Kelas V SD 4 Puyoh Kudus. Skripsi. Kudus: Universitas Muria Kudus.

Priyatni, Endah Tri. 2012. Membaca Sastra dengan Ancangan Literasi Kritis. Jakarta: Bumi Aksara.

Purba, Nurmaida. 2018. Peningkatan Motovasi Hasil Belajar SiswaPada Pembelajaran PKN dengan Menggunakan Metode Team Games Tournament di Kelas IV SD Negeri 060829 Medan Amplas. Jurnal Elementary School, 8 (2).

Setyowati, Yayuk Hermi. 2017. Penggunaan Metode Kooperatif Model Team Games Tournament Untuk Meningkatkan
Kemampuan Belajar Berhitung Perkalian dan Pembagian Siswa Kelas II. Premiere Educandum 7 (1): 87 - 94.

Silberman, Melvin. 2006. Active Learning. Penerbit Nusa Media. Bandung.

Subini, Nini. 2011. Mengatasi Kesulitan Belajar Pada Anak. Jogjakarta: Javalitera.

Surya, Hendra. 2014. Mengatasi Kesulitan Belajar. Jakarta: PT Elex Media Komputindo.

Undang-undang Nomor 20 tahun 2003 tentang Sistem Pendidikan Nasional

Widhiastuti, Ratieh., dan Fachrurrozie. 2014. Teams Games Tournament (TGT) Sebagai Metode Untuk Meningkatkan Keaktifan Dan Kemampuan Belajar. Jurnal Pendidikan Ekonomi Dinamika Pendidikan, IX (1): 48 - 56.

Wilujeng, Sri. 2013. "Peningkatan Aktivitas dan Hasil Belajar Siswa Melalui Model Team Games Tournament (TGT)". Jurnal of Elementary Education.

Yudianto, Wisnu D., Sumardi, Kamin., dan Berman, Ega T. 2014. Model Pembelajaran Teams Games Tournament Untuk Meningkatkan Hasil Belajar Siswa SMK. Journal of Mechanical Engineering Education, 1 (2). 